\title{
EVALUASI KECERNAAN PAKAN IKAN NILA Orechomis niloticus PADA TIGA STADIA YANG BERBEDA
}

\author{
Firsty Rahmatia, S.pi., M.Si ${ }^{1}$ \\ ${ }^{1}$ Program Studi Budidaya Perairan, Fakultas Perikanan dan ilmu kelautan, \\ Universitas Satya Negara Indonesia
}

\begin{abstract}
Feed is one of the most important part in intensive aquaculture system. Economically, the costs incurred for feed needs is $65 \%$ of total production costs. Fish obtain the energy to do all the activities of life and growth of feed consumed. Feed eaten will not be fully utilized by the fish for the energy fulfillment. Before being absorbed by the body and used for energy and growth, feed eaten will be through multiple pathways. Feed remains will back to the body in the form of feces. Thus, the ability to feed absorption by the fish depends on the ability of digestibility by the fish itself. The better the fish digestive ability the less the rest of the feed banished (feces). This research held to determine the digestibility of tilapia in three different stadia ( small, medium, and large). Then be viewed profiles enzyme activity associated with the stadia and ability of feed utilization. Large tilapia sized 7-8 cm with an average weight $25.17 \mathrm{~g}$, medium tilapia $4-5 \mathrm{~cm}$ with an average weight of $13.58 \mathrm{~g}$ and small tilapia $2-3 \mathrm{~cm}$ with an average weight 0.74 g. Total Feed Consumption (JKP ), Relative Growth (PR), Feed Conversion Ratio (FCR), Retention Fat (RL), Retention Protein (RP), digestibility level, and protease enzymes. Total consumption of large fish feed more than medium and small fish, but the relative growth of large and medium fish smaller than small fish. However, protease enzyme activity and digestibility did not show significantly different.
\end{abstract}

Keywords : Tilapia, feed, digestibility, different stadia

\begin{abstract}
ABSTRAK
Pakan merupakan salah satu bagian terpenting dalam budidaya secara intensif. Ditinjau dari segi ekonomi, biaya yang dikeluarkan untuk kebutuhan pakan mencapai $65 \%$ dari total biaya produksi. Ikan memperoleh energi untuk melakukan segala aktivitas kehidupan dan pertumbuhan dari pakan yang dikonsumsinya. Pakan yang dimakan tidak akan seluruhnya dimanfaatkan oleh ikan untuk pemenuhan energi tersebut. Sebelum diserap oleh tubuh dan dimanfaatkan sebagai sumber energi dan pertumbuhan, pakan yang dimakan akan melalui beberapa jalur terlebih dahulu. Sisa pakan yang tidak dapat diserap akan dikeluarkan kembali dari tubuh dalam bentuk feses. Dengan demikian, kemampuan penyerapan pakan oleh ikan bergantung pada kemampuan cerna pakan oleh ikan itu sendiri. Semakin baik kemampuan cerna ikan maka akan semakin sedikit sisa makanan yang dibuangnya (feses). Penelitian ini perlu dilakukan untuk mengetahui kecernaan ikan nila pada tiga stadia yang berbeda (kecil, sedang, dan besar). Kemudian dapat dilihat profil aktivitas enzim terkait dengan stadia dan kemampuan pemanfaatan pakan. Ukuran ikan nila besar yang
\end{abstract}


digunakan adalah $7-8 \mathrm{~cm}$ dengan bobot rata - rata 25,17 g/ekor, nila sedang $4-5 \mathrm{~cm}$ dengan bobot rata-rata 13,58 g/ekor dan nila kecil $2-3 \mathrm{~cm}$ dengan bobot rata - rata 0,74 g/ekor. Parameter yang diamati adalah Jumlah Konsumsi Pakan (JKP), Pertumbuhan Relatif (PR), Feed Conversion Ratio (FCR), Retensi Lemak (RL), Retensi Protein (RP), Kecernaan, dan enzim protease. Jumlah konsumsi pakan ikan besar lebih banyak daripada jumlah konsumsi pakan ikan sedang dan kecil, namun sebaliknya, pertumbuhan relatif ikan besar dan sedang lebih kecil daripada ikan kecil. Namun, aktivitas enzim protease dan kecernaan tidak memiliki perbedaan yang berbeda nyata.

\section{Kata kunci : Ikan nila, pakan, kecernaan, stadia berbeda}

\section{PENDAHULUAN}

Budidaya ikan melibatkan beberapa input seperti wadah atau tempat pemeliharaan, benih, pakan, obat-obatan, dan teknologi budidaya. Pakan merupakan salah satu bagian terpenting dalam budidaya terutama budidaya secara intensif. Ditinjau dari segi ekonomi, biaya yang dikeluarkan untuk kebutuhan pakan mencapai $65 \%$ dari total biaya produksi.

Ditinjau dari kegunaannya, pakan menjadi penting karena mempengaruhi pertumbuhan ikan yang dibudidayakan. Ikan memperoleh energi untuk melakukan segala aktivitas kehidupan dan pertumbuhan dari pakan yang dikonsumsinya. Akan tetapi, pakan yang dimakan tidak akan seluruhnya dimanfaatkan oleh ikan untuk pemenuhan energi tersebut. Sebelum diserap oleh tubuh dan dimanfaatkan sebagai sumber energi dan pertumbuhan, pakan yang dimakan akan melalui beberapa jalur terlebih dahulu.

Ikan akan mengambil pakan dengan mulut dan memakannya, selanjutnya masuk ke dalam sistem pencernaan dan dicerna menjadi molekul-molekul sederhana yang mampu diserap oleh tubuh. Pakan diserap oleh dinding usus dan masuk ke dalam sistem peredaran darah (Tytler dan Clow, 1985 dalam Fitriliyani, 2011). Sisa pakan yang tidak dapat diserap akan dikeluarkan kembali dari tubuh dalam bentuk feses. Dengan demikian, kemampuan penyerapan pakan oleh ikan bergantung pada kemampuan cerna pakan oleh ikan itu sendiri. Semakin baik kemampuan cerna ikan maka akan semakin sedikit sisa makanan yang dibuangnya (feses).

Sistem pencernaan terbagi atas tiga jenis, yaitu pencernaan mekanik, pencernaan kimiawi, dan pencernaan biologis (Affandi et al., 2009). Kebanyakan spesies ikan budidaya tidak memiliki gigi sehingga pencernaan mekanik di rongga mulut tidak terjadi. Ikan juga tidak memiliki rumen seperti ruminansia sebagai tempat berkembangnya bakteri sebagai pencerna biologis. Sehingga salah satu faktor yang paling mempengaruhi kemampuan cernanya adalah aktivitas enzim sebagai pencernaan kimiawi (Hepher, 1990 dalam Fitriliyani, 2011).

Berdasarkan hal tersebut, penelitian ini perlu dilakukan untuk mengetahui kecernaan ikan nila pada tiga stadia yang berbeda (kecil, sedang, dan besar). Untuk kemudian dapat dilihat profil aktivitas enzim terkait dengan stadia dan kemampuan pemanfaatan pakan. Penelitian ini bertujuan untuk mengevaluasi 
kualitas dan kecernaan pada ikan nila Oreochromis niloticus untuk ukuran kecil, sedang, dan ukuran besar.

\section{BAHAN DAN METODE}

\section{Waktu dan Tempat}

Penelitian dilakukan selama 3 bulan, bertempat di Laboratorium Akuakultur, Fakultas Perikanan dan Ilmu Kelautan, Universitas Satya Negara Indonesia.

\section{Prosedur Penelitian}

\section{Ikan Uji}

Ikan uji yang digunakan dalam penelitian ini adalah ikan nila. Ukuran ikan nila besar yang digunakan adalah $7-8 \mathrm{~cm}$ dengan bobot rata - rata $25,17 \mathrm{~g} / \mathrm{ekor}$, nila sedang 4-5 cm dengan bobot rata-rata 13,58 g/ekor dan nila kecil $2-3 \mathrm{~cm}$ dengan bobot rata - rata 0,74 g/ekor. Ikan nila dipelihara di dalam wadah akuarium berukuran dengan kepadatan 10 ekor/akuarium (nila besar), 20 ekor/akuarium (nila sedang), dan 30 ekor/akuarium (nila kecil). Ikan uji tersebut kemudian diadaptasikan (aklimatisasi) terhadap pakan, media hidup dan wadah pemeliharaan selama 2 hari. Selanjutnya dipuasakan selama 24 jam untuk menghilangkan sisa pakan dalam saluran pencernaan ikan.

\section{Pakan Uji}

Pakan uji yang digunakan adalah pakan komersil. Sebelum diberikan, pakan uji telah dicampurkan dengan kromium trioksida $\left(\mathrm{Cr}_{2} \mathrm{O}_{3}\right)$ sebanyak 0,5\% terlebih dahulu (repelleting) sebagai indikator kecernaan (NRC, 1993).

Manajemen pemberian pakan adalah dilakukan dua kali sehari yaitu pada pukul 07.00 dan 16.00 secara at satiation (sekenyangnya). Sebelum pemberian pakan, akuarium disifon untuk menghilangkan sisa-sisa pakan dan kotoran. Pada hari ke-5 setelah ikan diberi pakan perlakuan, feses mulai dikumpulkan kemudian disimpan dalam botol film. Feses yang terkumpul tersebut disimpan dalam freezer untuk menjaga kesegarannya.

\section{Analisis Kimia}

Analisis proksimat dilakukan terhadap pakan perlakuan dan ikan uji. Analisis yang dilakukan pada pakan perlakuan meliputi kadar protein, lemak, serat kasar, kadar abu, dan kadar air. Sedangkan untuk ikan uji meliputi analisis protein, lemak, dan kadar air.

Analisis proksimat untuk protein dilakukan dengan metode Kjeldahl, lemak pakan dilakukan dengan metode Soxhlet, lemak ikan dilakukan dengan metode Folch, kadar abu dengan pemanasan dalam tanur bersuhu $600{ }^{\circ} \mathrm{C}$, serat kasar menggunakan metode pelarutan sampel dengan asam dan basa kuat serta pemanasan, dan kadar air dengan pemanasan dalam oven bersuhu $105-110{ }^{\circ} \mathrm{C}$ (Takeuchi, 1988).

\section{Analisis kecernaan}


Analisis kecernaan dilakukan setelah pengumpulan feses telah selesai dilakukan, yaitu pada akhir penelitian setelah pemeliharaan selama 30 hari. Pengukuran kinerja pertumbuhan juga dilakukan pada akhir pemeliharaan. Feses yang telah terkumpul kemudian dikeringkan menggunakan oven bersuhu $105-110{ }^{\circ} \mathrm{C}$ selama 5-6 jam. Selanjutnya dilakukan analisis kromium trioksida $\mathrm{Cr}_{2} \mathrm{O}_{3}$ pada feses yang sudah dikeringkan. Analisis $\mathrm{Cr}_{2} \mathrm{O}_{3}$ dalam pakan dan feses dilakukan dengan proses oksidasi dan dilanjutkan dengan pembacaan nilai absorban menggunakan spektrofotometer dengan panjang gelombang $350 \mathrm{~nm}$.

\section{Parameter Pengamatan}

\section{Jumlah Konsumsi Pakan (JKP)}

Jumlah pakan yang diberikan setiap hari dikurangi jumlah pakan yang tersisa. Pakan yang diberikan selama percobaan kemudian dijumlahkan.

\section{Kecernaan}

Parameter kecernaan yang dihitung berdasarkan Watanabe (1988) dan NRC (1993) adalah sebagai berikut :

$$
\begin{array}{ll}
\text { Kecernaan protein } & =100-\left[100 \times \text { a } / \mathrm{a}^{\prime} \mathrm{x} \mathrm{b} / \mathrm{b}^{\prime}\right] \\
\text { Energi tercerna } & =\text { Energi pakan }-\left(\text { Energi feses } \mathrm{x} \mathrm{n} / \mathrm{n}^{\prime}\right) \\
\text { Kecernaan energi } & =[\text { Energi tercerna/Energi pakan }] \times 100 \% \\
\text { Kecernaan bahan } & =(\text { ADT-0,7AD }) / 0,3
\end{array}
$$

Keterangan :

$$
\begin{array}{ll}
\mathrm{a} & =\% \mathrm{Cr} 2 \mathrm{O} 3 \text { dalam pakan } \\
\mathrm{a}, & =\% \mathrm{Cr} 2 \mathrm{O} 3 \text { dalam feses } \\
\mathrm{b} & =\% \text { protein dalam pakan } \\
\mathrm{b}, & =\% \text { protein dalam feses } \\
\mathrm{n} & =\mathrm{mg} \mathrm{Cr} 2 \mathrm{O} 3 / \mathrm{g} \text { pakan } \\
\mathrm{n}, & =\mathrm{mg} \mathrm{Cr} 2 \mathrm{O} 3 / \mathrm{g} \text { feses } \\
\mathrm{ADT} & =\text { nilai kecernaan pakan uji } \\
\mathrm{AD} & =\text { nilai kecernaan pakan acuan }
\end{array}
$$

\section{Tingkat Kelangsungan Hidup (Survival Rate)}

Tingkat kelangsungan hidup dihitung berdasarkan persamaan:

$$
\mathrm{SR}=[\mathrm{Nt} / \mathrm{No}] \times 100 \%
$$

Keterangan :

$$
\begin{array}{lll}
\mathrm{SR} & = & \text { Kelangsungan hidup ikan } \\
\mathrm{Nt} & = & \text { Jumlah ikan pada akhir pemeliharaan } \\
\mathrm{No} & = & \text { Jumlah ikan pada awal pemeliharaan }
\end{array}
$$

\section{Pertumbuhan Relatif}

Pertumbuhan relatif dihitung dengan menggunakan rumus :

$$
\mathrm{PR}=[(\mathrm{Wt}-\mathrm{Wo}) / \mathrm{Wo}] \times 100 \%
$$

Keterangan :

$$
\begin{array}{lll}
\mathrm{PR} & = & \text { Pertumbuhan relatif } \\
\mathrm{Wt} & = & \text { Biomassa ikan pada waktu } \mathrm{t}(\mathrm{gram}) \\
\mathrm{Wo} & = & \text { Biomassa ikan pada awal pemeliharaan }(\mathrm{gram})
\end{array}
$$

Konversi Pakan (Feed Conversion Ratio, FCR) 
Efisiensi pakan dihitung dengan menggunakan rumus :

$$
\mathrm{FCR}=\{((\mathrm{Wt}+\mathrm{D}) / \mathrm{F})-\mathrm{Wo}]\}
$$

Keterangan :

$\begin{array}{lll}\mathrm{FCR} & = & \text { Konversi pakan } \\ \mathrm{F} & = & \text { Jumlah pakan kering yang diberikan } \\ \mathrm{Wt} & = & \text { Biomassa ikan pada waktu } \mathrm{t} \text { (gram) } \\ \mathrm{Wo} & = & \text { Biomassa ikan pada awal pemeliharaan (gram) } \\ \mathrm{D} & = & \text { Bobot ikan yang mati selama penelitian (gram) }\end{array}$

\section{Retensi Nutrien (protein, lemak, karbohidrat)}

Nilai retensi protein dihitung berdasarkan persamaan (Takeuchi, 1988); $\mathrm{RP}=[(\mathrm{F}-\mathrm{I}) / \mathrm{P}] \times 100 \%$

Keterangan :

$\begin{array}{lll}\mathrm{RP} & = & \text { Retensi nutrien }(\%) \\ \mathrm{F} & = & \text { Jumlah nutrien tubuh ikan pada akhir pemeliharaan (gram) } \\ \mathrm{I} & = & \text { Jumlah nutrien tubuh ikan pada awal pemeliharaan (gram) } \\ \mathrm{P} & = & \text { Jumlah nutrien yang dikonsumsi ikan (gram) }\end{array}$

\section{Analisis Data}

Desain penelitian adalah menggunakan Rancangan Acak Lengkap (RAL) satu faktor yaitu stadia ikan. Analisis sidik ragam (ANOVA) dilakukan dengan menggunakan perangkat lunak SPSS 16.00, apabila terdapat pengaruh yang berbeda nyata $(\mathrm{P}<0.05)$ maka dilakukan uji lanjut Tukey.

\section{HASIL DAN PEMBAHASAN}

\section{Hasil}

Hasil analisis proksimat pakan perlakuan yang digunakan dalam penelitian disajikan pada tabel di bawah ini.

Tabel 2. Hasil Analisis Proksimat Pakan (\% bobot basah)

\begin{tabular}{cccccc}
\hline $\begin{array}{c}\text { Kadar } \\
\text { Air }\end{array}$ & $\begin{array}{c}\text { Kadar } \\
\text { Abu }\end{array}$ & $\begin{array}{c}\text { Kadar } \\
\text { Protein }\end{array}$ & $\begin{array}{c}\text { Kadar } \\
\text { Lemak }\end{array}$ & $\begin{array}{c}\text { Kadar Serat } \\
\text { kasar }\end{array}$ & $\begin{array}{c}\text { Kadar } \\
\text { BETN }\end{array}$ \\
\hline 7.73 & 15.29 & 29.14 & 3.83 & 3.31 & 40.7 \\
\hline
\end{tabular}

Setelah 30 hari masa pemeliharaan maka diamati parameter-parameter kinerja pertumbuhan. Hasil pengamatan tersaji dalam tabel di bawah ini.

Tabel 3. Kinerja Pertumbuhan Ikan Nila

\begin{tabular}{|l|c|c|c|c|c|c|c|}
\hline $\begin{array}{l}\text { Stadia } \\
\text { Ikan }\end{array}$ & JKP & PR (\%) & FCR & RL (\%) & RP (\%) & KP (\%) & $\begin{array}{c}\text { Enzim } \\
\text { Protease }\end{array}$ \\
\hline Kecil & $49.54 \pm 17.19^{\mathrm{a}}$ & $117.56 \pm 26.45^{\mathrm{b}}$ & $2.05 \pm 1.11^{\mathrm{a}}$ & $0.04 \pm 0.01^{\mathrm{a}}$ & $0.05 \pm 0.04^{\mathrm{a}}$ & $56.92 \pm 12.52^{\mathrm{a}}$ & $1.13 \pm 0.83^{\mathrm{a}}$ \\
\hline Sedang & $65.76 \pm 13.84^{\mathrm{a}}$ & $25.47 \pm 7.26^{\mathrm{a}}$ & $2.59 \pm 1.19^{\mathrm{a}}$ & $0.20 \pm 0.07^{\mathrm{a}}$ & $0.09 \pm 0.04^{\mathrm{a}}$ & $55.22 \pm 6.90^{\mathrm{a}}$ & $0.90 \pm 0.30^{\mathrm{a}}$ \\
\hline Besar & $105.38 \pm 9.43^{\mathrm{b}}$ & $18.30 \pm 6.13^{\mathrm{a}}$ & $3.07 \pm 0.95^{\mathrm{a}}$ & $0.49 \pm 0.11^{\mathrm{b}}$ & $0.06 \pm 0.05^{\mathrm{a}}$ & $57.41 \pm 2.67^{\mathrm{a}}$ & $1.10 \pm 0.87^{\mathrm{a}}$ \\
\hline
\end{tabular}

Keterangan : Huruf superskript yang berbeda pada kolom yang sama menunjukkan hasil yang berbeda nyata $(\mathrm{P}<0.05)$.

JKP : Jumlah Konsumsi Pakan

PR : Pertumbuhan Relatif

FCR : Feed Convertion Ratio 


\section{RL : Retensi Lemak \\ RP : Retensi Protein \\ KP : Kecernaan Pakan}

\section{Pembahasan}

Ikan nila termasuk dalam famili Cichlidae yang memiliki sifat mouthbreeder atau memelihara telur dan larva dalam mulut. Klasifikasi ikan nila menurut Trewavas (1982) adalah sebagai berikut :

$\begin{array}{ll}\text { Filum } & \text { : Chordata } \\ \text { Kub Filum } & \text { : Vertebrata } \\ \text { Sub kelas } & \text { : Osteichtyes } \\ \text { Ordo } & \text { : Perchanthoptherigi } \\ \text { Sub Ordo } & \text { : Percoidea } \\ \text { Famili } & \text { : Cichlidae } \\ \text { Genus } & \text { : Oreochromis } \\ \text { Spesies } & \text { : Oreochromis niloticus }\end{array}$

Ikan nila memiliki bentuk tubuh memanjang, ramping dan relatif pipih. Ikan nila juga memilki kemampuan adaptasi yang baik dalam berbagai jenis air, tahan terhadap perubahan lingkungan, bersifat omnivor, mampu mencerna makanan secara efisien, memiliki pertumbuhan yang cepat serta tahan terhadap penyakit. Ikan nila bersifat omnivora dan dapat memanfaatkan fitoplankton, zooplankton, bakteri dan detritus sebagai pakan. Ikan nila juga diketahui memiliki kemampuan untuk memfilter fitoplankton dengan diameter kurang dari $5 \mu \mathrm{m}$ di perairan (Lovell, 1989).

Permintaan pasar akan ikan nila terus meningkat. Hingga tahun 2005, kebutuhan ikan nila di Jawa Barat baru terpenuhi sekitar $21 \%$. Sedangkan berdasarkan data National Fisheries Service selama tahun 2006, Amerika telah mengimpor 60.772 ton ikan nila yang didatangkan dari berbagai negara, termasuk diantaranya adalah Indonesia. Total ekspor ikan nila Indonesia pada tahun 2005 sebesar 151.363 ton dan terus meningkat hingga mencapai 206.904 ton pada tahun 2007 (FAO, 2009).

Padat tebar ikan nila sangat bervariasi, bergantung pada sistem budidaya yang diterapkan. Padat tebar dan produktivitas ikan nila pada beberapa sistem budidaya dapat dilihat pada tabel 1 .

Tabel 1. Padat tebar dan produktivitas ikan nila pada beberapa sistem budidaya

\begin{tabular}{|l|c|c|}
\hline \multicolumn{1}{|c|}{ Sistem budidaya } & Padat tebar $\left(\mathrm{ikan} / \mathrm{m}^{3}\right)$ & Produktivitas $\left(\mathrm{kg} / \mathrm{m}^{3}\right)$ \\
\hline Ekstensif & $0,1-0,2$ & $0,03-0,07$ \\
\hline Semi intensif & $0,2-0,6$ & $0,4-0,8$ \\
\hline $\begin{array}{l}\text { Intensif (penambahan aerasi saat DO } \\
\text { rendah) }\end{array}$ & $1-3$ & $0,5-1$ \\
\hline Intensif (aerasi kontinu) & $1-3$ & $0,8-15$ \\
\hline Intensif (aerasi kontinu dan ganti air) & $5-10$ & $2-10$ \\
\hline Kolam air deras (raceways) & $70-200$ & $70-200$ \\
\hline Karamba (cages) & $50-100$ & $50-300$ \\
\hline
\end{tabular}

Sumber: Popma dan Lovshin (1996)

Makanan merupakan salah satu komponen dalam kegiatan budidaya yang baru akan bernilai guna bagi tubuh (sebagai sumber materi dan energi) setelah 
melalui proses pencernaan, dan penyerapan terlebih dahulu. Fisiologi pencernaan dan penyerapan menyangkut hal-hal berikut :

- Struktur alat pencernaan, berperan sebagai tempat berlangsungnya proses pencernaan dan penyerapan makanan.

- Biokimia dari bahan-bahan yang terkait dengan proses pencernaan, antara lain : zat makanan, enzim, mukus, asam khlorida, cairan empedu, garam bikarbonat, dan hormon.

- Mekanisme pencernaan dan penyerapan zat makanan, yakni mekanisme fisik dan kimia serta interaksi antara komponen-komponen yang terkait dengan pencernaan dan penyerapan sehingga makanan dapat dicerna, diserap, dan selanjutnya dimanfa'atkan oleh tubuh ikan.

Struktur saluran pencernaan ikan terdiri atas; mulut, rongga mulut, faring, esofagus, lambung, pilorus, usus, rektum, kloaka, dan anus. Sementara struktur kelenjar pencernaan meliputi hati, kantung empedu, dan pankreas. Pada proses pencernaan terjadi proses penyederhanaan makanan melalui bahan yang sederhana dan melarut yang dengan mudah dapat diserap dan diedarkan ke seluruh tubuh melalui sistem peredaran darah. Pencernaan terjadi secara fisik (mekanik), kimiawi, dan biologi. Kombinasi inilah yang menyebabkan perubahan makanan dari yang asalnya bersifat kompleks menjadi senyawa sederhana (Affandi et al., 2009).

Pada penelitian ini, parameter pertama yang diamati adalah jumlah konsumsi pakan. Parameter ini menunjukkan jumlah pakan yang dimakan oleh ikan uji. Jumlah konsumsi pakan menunjukkan palatabilitas pakan. Jumlah pakan yang dikonsumsi menunjukkan perbedaan yang berbeda nyata $(\mathrm{P}<0.05)$. JKP oleh ikan nila besar secara keseluruhan dua kali lipat lebih banyak dari pada pakan yang dikonsumsi oleh ikan sedang dan kecil. Hal ini dikarenakan ukuran yang lebih besar membuat kebutuhan energi semakin meningkat, sehingga kebutuhan akan pakan juga meningkat, didukung oleh kapasitas organ pencernaan untuk pakan akan lebih besar dan daya tampung lebih tinggi.

Pakan yang dikonsumsi ikan nila selama 30 hari dimanfaatkan ikan sebagai sumber energi untuk metabolisme basal dan pertumbuhan, secara kuantitatif dapat dilihat dari nilai parameter kedua yaitu pertumbuhan relatif (PR). Berdasarkan hasil pertumbuhan relatif menunjukkan hasil yang berbeda nyata $(\mathrm{P}<0.05)$, ikan nila kecil menunjukkan angka yang jauh lebih tinggi dari ikan nila sedang dan besar. Hal ini disebabkan oleh laju pertumbuhan pada stadia ini (juvenil) berada pada fase kecepatan maksimum yang kemudian akan melambat pada stadia ikan besar (dewasa). Ketika dewasa energi yang diperoleh tidak hanya digunakan untuk pertumbuhan somatik akan tetapi sebagian digunakan untuk pertumbuhan gonad atau reproduktif (Effendi, 2004).

Selanjutnya perbandingan jumlah pakan yang dikonsumsi dengan kinerja pertumbuhan ikan uji menggambarkan nilai konversi pakan (FCR). Berdasarkan Tabel 3, nilai FCR semua perlakuan tidak baik (FCR $>2$ ). Tingginya nilai konversi pakan dapat disebabkan oleh faktor nilai nutrisi (Guillaume, 2001) dan stabilitas pakan (Watanabe et al., 1983).

Nilai retensi protein dan retensi lemak menggambarkan adanya pemanfaatan nutrien pakan yang telah dicerna oleh tubuh ikan, diserap, dan disimpan untuk menghasilkan energi (Lovell, 1989). Kandungan protein pakan yang optimal pada 
ikan dipengaruhi oleh beberapa faktor seperti keseimbangan antara protein dan energi, komposisi asam amino, dan kecernaan protein (Halver, 1989).

Berdasarkan Tabel 3, semua perlakuan menunjukkan nilai retensi protein yang sangat rendah $(<1 \%)$. Menurut Abdel-tawwab et al. (2008), perubahan kandungan protein dan lemak dalam tubuh ikan dapat dikaitkan dengan perubahan sintesis dalam tubuh, tingkat penyerapan otot dan atau perbedaan tingkat pertumbuhan. Namun pada penelitian ini, nilai retensi protein baik pada ikan kecil maupun besar menunjukkan nilai yang hampir sama. Parameter kinerja pertumbuhan terakhir yang diamati adalah retensi lemak ikan. Seperti halnya retensi protein, semua perlakuan menunjukkan nilai retensi lemak yang rendah $(<1 \%)$.

Kecernaan kimiawi pakan terkait dengan aktivitas enzimatis yang terdapat pada saluran pencernaan. Enzim adalah katalisator biologis dalam reaksi kimia yang sangat dibutuhkan dalam kehidupan. Enzim adalah protein, yang disintesis dalam sel dan dikeluarkan dari sel yang membentuknya melalui proses eksositosis. Enzim yang disekresikan ke luar sel digunakan untuk pencernaan di luar sel (di dalam rongga pencernaan) atau disebut "extra cellular digestion", sedangkan enzim yang dipertahankan dalam sel digunakan untuk pencernaan dalam sel itu sendiri atau disebut "intra celuller digestion" (Affandi et al,. 2004). Enzim pencernaan yang disekresikan dalam rongga pencernaan berasal dari selsel mukosa lambung, pilorik kaeka, pankreas dan mukosa usus (Halver dan Hardy, 2002 dalam Fitriliyani, 2011 ).

Pada penelitian ini, nutrien yang menjadi fokus utama adalah protein, karena protein berfungsi sebagai sumber energi untuk tumbuh. Enzim yang terkait dengan kecernaaan protein adalah enzim protease. Keberadaan enzim tergantung pada stadia dan kelengkapan organ pencernaan yang dimiliki oleh ikan. Ikan besar memiliki organ yang lebih sempurna dibandingkan dengan ikan kecil sehingga aktivitas enzimnya akan lebih tinggi. NAS (1983) menyatakan bahwa tingkat kecernaan terhadap suatu jenis pakan bergantung kepada kualitas pakan, komposisi bahan pakan, kandungan gizi pakan, jenis serta aktivitas enzim-enzim pencernaan pada sistem pecernaan ikan, ukuran dan umur ikan serta sifat fisik dan kimia perairan.

Nilai kecernaan yang tinggi terkait dengan serat kasar yang terkandung di dalam pakan, semakin rendah kadar serat kasar maka ikan akan lebih mudah mencerna dan menyerap nutrien termasuk protein. Bedasarkan uji statistik (Tabel 3 ), enzim protease yang terkandung pada ikan kecil, ikan sedang dan ikan besar menunjukkan nilai yang tidak berbeda nyata $(\mathrm{P}>0.05)$. Dengan demikian, dapat disimpulkan bahwa ikan nila mulai ukuran $2-3 \mathrm{~cm}$ diduga telah memiliki sistem organ dan kelenjar pencernaan yang sempurna, sehingga kemampuan cernanya dapat menyamai nila ukuran yang lebih besar.

\section{KESIMPULAN}

\section{Kesimpulan}

Jumlah konsumsi pakan ikan besar lebih banyak daripada jumlah konsumsi pakan ikan sedang dan kecil, namun sebaliknya, pertumbuhan relatif ikan besar dan sedang lebih kecil daripada ikan kecil. Ikan nila mulai ukuran 2-3 cm diduga 
telah memiliki sistem organ dan kelenjar pencernaan yang sempurna, sehingga kemampuan cernanya dapat menyamai nila ukuran yang lebih besar.

\section{DAFTAR PUSTAKA}

Abdel-tawwab, M, Ahmad, MH, Abdel-Hadi, YM, Seden, MEA. 2008. Use of spirulina Spirulina platensis as a growth and immunity promoter for nile tilapia, Oreochromis niloticus (1.) fry challenged with pathogenic Aeromonas hydrophila. 8th International Symposium on Tilapia in Aquaculture 2008.

Affandi, R, Sjafei, DS, Rahardjo, MF, Sulistiono, 2009. Fisiologi ikan: Pencernaan dan penyerapan makanan. Fakultas Perikanan dan Ilmu Kelautan - Institut Pertanian Bogor.

Effendi, I. 2004. Pengantar Akuakultur. Penebar Swadaya, Jakarta

Fitriliyani, I. 2011. Aktifitas enzim saluran pencernaan ikan nila (Oreohromis niloticus) dengan pakan mengandung tepung daun lamtoro (Leucaena leucophala) terhidrolisis dan tanpa hidrolisis dengan ekstrak enzim cairan rumen domba. Bioscientiae: Volume 8, Nomor 2, Juli 2011, Halaman 16-31.

[FAO] Food and Agricultural Organization. 2009. Tilapia market report - January 2008. http: //www.fao.org [April 25 2009 ].

Guillaume, J. 2001. Nutrition and Feeding of Fish and Crustaceans. University of Aberdeen, United Kingdom.

Halver, JE. 1989. Fish Nutrition, second ed. Academy Press Inc, New York.

Lovell, T. 1989. Nutrition and Feeding of Fish. Van Nostrand Reinhold, New York.

[NAS] National Academy of Science. 1983. Nutrient requirement of warmwater fish and shellfish. Revised Edition. National Academic Press, Washington DC, pp. 1-50.

[NRC] Nutritional Research Council. 1993. Nutrient Requirement of Fish. National Academic Press, Washington DC, pp. 43-44.

Popma TJ, Lovshin LL. 1996. World prospect for commercial production of tilapia. Research and Development Series No. 41. International Center for Aquaculture and Aquatic Environmens. Departement of Fisheries and Allied Aquacultures Auburn University. Alabama. 23 p.

Takeuchi, T. 1988. Laboratory Work Chemical Evaluation of Dietary Nutriens. In: Fish Fish Nutrition and Mariculture. Watanabe, T. Department of Aquatic Biosience. Tokyo University of Fisheries. JICA p. 179-226.

Trewavas, E. 1982. Tilapia : taxonomy and speciation in : Pullin, R.S.V., LoweMcConnel, R.H., The biology and culture of tilapias. ICLARM. Manila. The philippines. p: 3-14.

Watanabe, T, Cho, CY, Cowey, CB. 1983. Finfish Nutrition in Asia. Approaches to Research and Development, Tokyo University of Fisheries. 